\title{
Social Psychiatry in Germany in the Twentieth Century: Ideas and Models
}

\author{
HEINZ-PETER SCHMIEDEBACH and STEFAN PRIEBE*
}

\section{Introduction}

In the first decades of the twentieth century, German-language papers were published which included the term "soziale Psychiatrie" in their titles. "At the same time modern concepts of extramural psychiatric care were being developed. Yet, the meaning of "sozial" ("social" in English) varied widely. This was partly due to its ambiguity. "Social" can be used in the sense of small communities or the wider public; it refers to interpersonal relationships, or to relationships between individuals and social groups or other communities. ${ }^{2}$ According to this latter meaning, "social" can emphasize the interests of social groups rather than those of the individual. This is how the term was used at the end of the 1920 s and during the National Socialist era. On the other hand, "social" may indicate a friendly and humane intention, a philanthropic approach. It was in this sense that the term was widely used in the 1970s when philanthropic psychiatrists and others called for psychiatric reform and the closure or downsizing of asylums for the mentally ill. Moreover, in association with psychiatry, it can mean both the social dimension of mental illness (including the aetiology) that is assumed to lie in human relationships and in social circumstances, and the social and economic effects of mental illness. In parallel with these shifting meanings of the term "social", the established models of twentieth-century ambulant psychiatric care also showed a variety of structural characteristics.

Recent research on the history of social psychiatry has focused on either particular persons or the development in selected periods and regions. ${ }^{3}$ We present here some results

\footnotetext{
*Heinz-Peter Schmiedebach, Dr med. habil., Institut für Geschichte und Ethik der Medizin, UKE Hamburg, Martinistraße 52, D-20246 Hamburg, Germany; p.schmiedebach@uke. uni-hamburg.de; Stefan Priebe, FRCPsych, Dr med. habil., Dipl.-Psychologe, St Bartholomew's and the Royal London School of Medicine, Academic Unit Newham Centre for Mental Health, London E13 8SP, UK.

${ }^{1}$ Georg Ilberg, 'Soziale Psychiatrie', Monatsschr. Soz. Med., 1903, 1: 321-29, 393-98; Max Fischer, 'Die soziale Psychiatrie im Rahmen der sozialen Hygiene und allgemeine Wohlfahrtspflege', Allg. Z. Psychiatrie, 1919, 75: 529-48; Johannes Enge, Soziale Psychiatrie, Berlin, Adler, 1919.

${ }^{2}$ Stefan Priebe and Asmus Finzen, 'On the different connotations of social psychiatry', Soc. Psychiatry
}

Psychiatr. Epidemiol., 2002, 37: 47-9; Stefan Priebe and Heinz-Peter Schmiedebach, 'Soziale Psychiatrie und Sozialpsychiatrie. Zum historischen Gebrauch der Begriffe', Psychiatr. Praxis, 1997, 24: 3-9; Asmus Finzen and Ulrike Hoffmann-Richter (eds), Was ist Sozialpsychiatrie. Eine Chronik, Bonn, PsychiatrieVerlag, 1995.

${ }^{3}$ Klaus Dieter Waldmann, 'Die Realisierung der Rodewischer Thesen zu DDR-Zeiten. Versuch einer Analyse aus heutiger Sicht', Psychiatr. Praxis, 1998, 25: 18-22; Herbert Loos, 'Anerkannte Unordnungein Rückblick auf die Psychiatrie-Entwicklung in der DDR', in Aktion psychisch Kranker und Arbeitskreis der Ärztlichen Leiter (eds), Grundlagen und Gestaltungsmöglichkeiten der Versorgung psychisch Kranker und Behinderter in der Bundesrepublik und auf dem Gebiet der ehemaligen DDR, Cologne, Rheinland-Verlag, 1992, pp. 174-80; Dirk Blasius, Der Umgang mit Unheilbaren. Studien zur Sozialgeschichte 


\section{Heinz-Peter Schmiedebach and Stefan Priebe}

derived from the work of a research group that has studied the history of mental health care in Germany throughout the twentieth century. ${ }^{4}$ We surveyed twenty-six psychiatric journals, looking for articles related to extramural care and social psychiatry. Our paper, therefore, is based only on published material. Yet it covers the whole of the twentieth century and that in itself poses some problems. On the one hand, an investigation spanning a hundred years provides the opportunity to detect continuities, discontinuities, similarities, and differences on a comparative basis. On the other, one can only consider trends; it is impossible to render a deep analysis of psychiatric care in the five different German states and political systems that existed during this period. Besides the investigation of the changing meanings of the term "social psychiatry", we will discuss the Bavarian model of extramural psychiatric care developed by Gustav Kolb and the Gelsenkirchen model created and implemented by Friedrich Wendenburg during the 1920s. We will also refer to the post-war situation in Germany and deal with the psychiatric reform movements of the 1960s and 1970s. With respect to the issues under consideration, it can be argued that "social" psychiatric care in the first decades of the twentieth century was motivated more by pragmatic interests, such as reducing costs associated with the mentally ill or discharging patients from overcrowded asylums, than by political or philanthropic concerns. By way of its extramural expansion, psychiatry extended its influence over people who had previously lived outside the psychiatrists' realm. Despite the very pragmatic motives for this expansion, the reform oriented psychiatrists of the 1960s in the German Democratic Republic and of the 1970s in the Federal Republic of Germany considered this development in the early decades of the twentieth century a positive example of the humane intentions of psychiatry and referred to it as based on traditional humane and philanthropic attitudes. This overestimation of the humane motivations of the earlier reforms helped them to distance themselves from the dark and anti-humane activities of psychiatrists in the National Socialistic era. ${ }^{5}$ They therefore sought a reference to positive activities in the history of German psychiatry, and the early social-psychiatric models provided that point of reference. While in the GDR these psychiatrists were not part of a socio-political movement, the doctors in the FRG could use social protest movements to empower their activities. Despite the fact that the newly emerging specialty of social psychiatry tried to launch a scientific research programme, it largely failed to establish itself within university medical faculties.

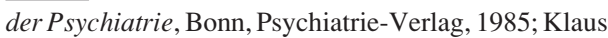
Dörner (ed.), Ende der Veranstaltung. Anfänge der Chronisch-Kranken-Psychiatrie, Gütersloh, Hoddis, 1998; Klaus Dörner, 'Die Psychiatriereform in Deutschland in ihren Auswirkungen auf die stationäre Versorgungspraxis', Symptom. Leipziger Beiträge zu Psychiatrie und Verrücktheit, 2000, 5: 90-5; Heinz Häfner, 'Ein Vierteljahrhundert Rehabilitation psychisch Kranker in Deutschland', Öffent. Gesundheitswesen, 1997, 59: 69-78; Asmus Finzen and Ulrike Hoffmann-Richter, 'Sozialpsychiatrie, soziale Psychiatrie 1911', Psychiatr. Praxis, 1995, 22: 167-70; Klaus Weise, '35 Jahre Rodewischer Thesen. Erinnerung und Ausblick’, Soz. Psychiatr.,
1998, H 3: 32-4; Achim Thom and Erich Wulff (eds), Psychiatrie im Wandel: Erfahrungen und Perspektiven in Ost und West, Bonn, Psychiatrie-Verlag, 1990.

${ }^{4}$ To this group belonged Thomas Beddies, Stefan Priebe, Heinz-Peter Schmiedebach, Jörg Schulz. Our sincere thanks to the other members of the group and to the Deutsche Forschungsgemeinschaft (DFG) for the support of our research.

Hans-Walter Schmuhl, 'Die Patientenmorde', in Angelika Ebbinghaus, Klaus Dörner (eds), Vernichten und heilen. Der Nürnberger Ärzteproze $\beta$ und seine Folgen, Berlin, Aufbau. Verlag, 2001, pp. 295-328, on p. 297. 


\section{Social Psychiatry in Germany in the Twentieth Century}

\section{The Term "Soziale Psychiatrie"}

From the middle of the nineteenth century the term "sozial" was linked to medicine in numerous ways: first, it described a communal or public perspective of medicine, according to which a large number of diseases were caused by damaging social circumstances. Second, "sozial" was used to indicate political options relating to the social problems of society. In this context, the word stood for the establishment of democracy, equality, welfare, education, and health. ${ }^{6}$ Third, "sozial" was used in the sense of humane and philanthropic interaction, and this aspect was particularly relevant to doctors' attitudes towards the mentally ill. Despite the fact that in the middle of the nineteenth century German psychiatrists did not use the term "soziale Psychiatrie", a few contemporary psychiatrists, like Wilhelm Griesinger and Ludwig Mayer, referred to the concept of extramural family care. In this context W Rössler and A Riecher-Rössler have discussed Griesinger and his contributions to the concept of community care in the nineteenth century, ${ }^{7}$ and Martin Schrenk has dealt with the social-psychiatric consequences of Griesinger's work. ${ }^{8}$

At the end of the nineteenth century, the term "sozial" became associated with newly emerging disciplines, such as "social hygiene" or "social pathology". 9 It was linked to issues of public health and to the "Volkskörper" in the sense of a socio-ethnic body. The concept of social hygiene tended to regulate all kinds of social relationships and intercourse by means of scientifically sanctioned interventions, very often characterized in terms of "rational" management. ${ }^{10}$ Alfred Grotjahn, one of the German fathers of social hygiene or social medicine, applied these interventions to sexuality and procreation, calling for eugenic measures to regulate the number of offspring. He described this as a "rational" method of controlling propagation" ${ }^{11}$ by preventing the birth of handicapped children and thus improving the health of the nation. A majority of German doctors thought that 60 to 70 per cent of all mental diseases were caused by hereditary factors.

It was in 1903 that the term "social" was first linked to psychiatry, when Georg Ilberg from the Groß-Schweidnitz asylum in Saxony wrote a paper entitled simply 'Soziale Psychiatrie'. ${ }^{12}$ Ilberg defined social psychiatry as a theory of the detrimental influences that affected the mental health of the whole population (Gesamtheit) and of useful means

\footnotetext{
${ }^{6}$ Rudolf Virchow, 'Mittheilungen über die in Oberschlesien herrschende Typhus-Epidemie',

Virchows Arch. Path. Anat. Physiol. Klin. Med., 1849, 2: 143-322.

${ }^{7}$ W Rössler, A Riecher-Rössler, U Meise, 'Wilhelm Griesinger and the concept of community care in 19th century Germany', Hosp. Community Psychiatry, 1994, 45: 818-25.

${ }^{8}$ Martin Schrenk, 'Griesingers neuropsychiatrische Thesen und ihre sozialpsychiatrische Konsequenzen', Nervenarzt, 1968, 39: 441-50.

${ }^{9}$ See George Rosen, 'What is social medicine?', in George Rosen (ed.), From medical police to social medicine: essays on the history of health care, New York, Science History Publications, 1974, pp. 60-119.
}

\footnotetext{
${ }^{10}$ See Heinz-Peter Schmiedebach, 'Gesundheit und Prävention in Abhängigkeit vom Gesellschaftsbegriff im 19. Jahrhundert', in Sigrid Stöckel and Ulla Walter (eds), Prävention im 20. Jahrhundert. Historische Grundlagen und aktuelle Entwicklungen in

Deutschland, Weinheim and Munich, Juventa, 2002, pp. 26-38.

${ }^{11}$ Alfred Grotjahn, Soziale Pathologie. Versuch einer Lehre von den sozialen Beziehungen der menschlichen Krankheiten als Grundlage der sozialen Medizin und der sozialen Hygiene,

2nd ed., Berlin, Hirschwald, 1915, pp. 489,493 .

${ }^{12}$ Ilberg, op. cit., note 1 above, pp. 321-9, 393-8.
} 


\section{Heinz-Peter Schmiedebach and Stefan Priebe}

for their prevention. Ilberg agreed that about 60 to 70 per cent of all mental diseases exhibited an hereditarian component and thus, not surprisingly, held that the first task of social psychiatry was to prevent intermarriage between healthy and mentally ill persons. The second task concerned the fight against syphilis, which caused progressive paralysis and dementia paralytica. Third, he called for a campaign against excessive alcohol consumption. Fourth, he felt that it was essential for several professional groups to become familiar with psychiatric knowledge, among them lawyers, priests, and teachers. In his view, teachers in particular should be well informed about psychiatric and mental health issues because they acted as career advisers. If they acquired enough psychiatric knowledge to evaluate the psychic and mental qualities of their pupils, then they could gain control over them and their families and influence their vocational choice. Ilberg stressed that because a large number of pupils chose their trade or profession without due consideration of their intellectual abilities and their mental powers, they ended up being severely taxed by their vocational training. Thus, they were forced to change their line of work and this led to unnecessary costs and misery. Ilberg believed teachers could prevent this. Social psychiatry in the early twentieth century dealt with the relationship between mental illness and society. The social consequences of mental and intellectual peculiarities and disorders was discussed in terms of social solutions. Ilberg's "social psychiatry" exhibited its competence in that field. Social psychiatry contributed to a rational organization of modern society, i.e. to the modern process of advancing the medicalization of social intercourse.

In 1911 Max Fischer, psychiatric director of the Wiesloch asylum, used the terms "soziale Psychiatrie" and "sozialpsychiatrisch" in a paper which he read at the eightythird meeting of German scientists and physicians. In this paper he advocated psychiatric care outside the asylums and called this kind of extramural psychiatry "soziale Psychiatrie". He made reference to the Badische Hilfsverein für Geisteskranke, a relief organization founded in 1872 for the discharged mentally ill, and maintained that this organization would have to continue its work as long as there was no other social psychiatric structure in place. ${ }^{13}$ After the First World War the debate about social psychiatry became more intense, partly due to the huge social and economic problems that arose out of Germany's military defeat. On the one hand, this debate emphasized socio-political aspects and problems of public assistance; on the other, it focused on the academic status of the newly emerging discipline of psychiatry and was concerned with contents and programmes. The integration of psychiatry into medical science was completed in 1901, from when on it was a separate specialty in the final medical examination. In 1919 Johannes Enge from the asylum in Lübeck and Fischer again took up the question of social psychiatry. Fischer argued that psychiatry was confronted with social problems everywhere; at stake was the family as well as the community, the "race", and the state. He emphasized that without intense investigation of the social causes and without effective social-medical activities, particularly in prevention and hygiene, there would be no psychiatry. In other words, without social psychiatry there would be no

\footnotetext{
${ }^{13}$ Max Fischer, 'Neue Aufgaben der Psychiatrie in Baden', Allg. Z. Psychiatrie, 1912, 69: 34-68; see also
}

Finzen and Hoffmann-Richter, op. cit., note 3 above, pp. 167-70. 


\section{Social Psychiatry in Germany in the Twentieth Century}

psychiatry. ${ }^{14}$ In this context, he also addressed the problem of racial hygiene and called for marriage to be forbidden to degenerates, idiots, and severe epileptics. ${ }^{15}$ He suggested reforms in the structure of public psychiatric assistance as organized around the asylum. The asylum with its doctors was seen as the key central institution that controlled all activities of ambulant psychiatric care in a defined district. In addition, he recommended the establishment of a network of welfare centres to deliver public assistance. All these efforts would target the family, which in Fischer's view was the most relevant object of his endeavours.

Enge dealt with this topic in a similar way. In 1919 he published his monograph, Soziale Psychiatrie, in which he stated that psychiatry had increasingly become a social science. ${ }^{16}$ Yet Enge was primarily interested in the socio-political tasks of psychiatry. Like Fischer, he underlined the importance of prevention and promoted both sterilization and castration as a means of selection and purging "tainted blood". ${ }^{17}$ Moreover, Enge defined another task of social psychiatry: the protection of the general public from "antisocial" individuals. He maintained that psychiatrists did society a good turn when they used their expertise to consign as many "antisocial" individuals as possible to asylums and held them there for a very long time. ${ }^{18}$ These concepts of social psychiatry addressed not only the social causes of mental illness, but also the concerns of a general public, a "race" and a nation, driven by fear of a growing number of lunatics and mental degenerates who were seen as a danger to the survival of the nation. In the light of these concerns, the trend towards medical surveillance of the mentally ill living outside the asylums became an integral part of the German variety of social psychiatry during the first half of the twentieth century.

This tendency toward social control and selection became stronger during the 1920s. ${ }^{19}$ Otto Rehm from Bremen argued that the main task of social psychiatry was to identify individuals who deviated from what he called the normal social behaviour of the average individual. ${ }^{20}$ Rehm used poorly defined notions, such as normal, deviation and average. By doing so he addressed primarily the social and political prejudices of many psychiatrists. Though psychiatrists at that time were eager to define generally accepted criteria of normal behaviour, their efforts had not fostered concrete results. ${ }^{21}$ Therefore the terminology used by Rehm was neither precise nor in line with clear medical definitions. According to Rehm, social psychiatry had to select and segregate "detrimental elements" so as to avoid hereditary transmission. This task could be performed not only by sterilization and castration, but also by euthanasia; in this context he quoted the book by Karl Binding and Alfred Hoche on the extermination of "unworthy" lives. ${ }^{22}$ Because of the threat posed to culture, one had to carry out ruthlessly every measure that was useful in

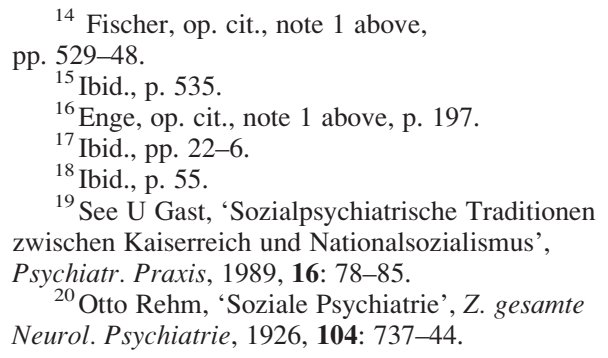

\footnotetext{
${ }^{21}$ See Heinz-Peter Schmiedebach, “ "Abweichung vom Durchschnitt im Sinne der Zweckmäßigkeit”Der psychiatrische Blick auf die psychische Normalität', in Volker Hess (ed.), Normierung der Gesundheit. Messende Verfahren der Medizin als kulturelle Praxis um 1900, Husum, Matthiesen, 1997, pp. 39-52.

${ }^{22}$ Rehm, op. cit., note 20 above, p. 741; Karl Binding and Alfred Hoche, Die Freigabe der Vernichtung lebensunwerten Lebens: ihr Mass und ihre Form, Leipzig, Meiner, 1920.
} 


\section{Heinz-Peter Schmiedebach and Stefan Priebe}

promoting the good and eradicating the inferior and the bad. ${ }^{23}$ Rehm maintained that the main task of social psychiatry was to evaluate specific mental diseases and disturbances in the light of possible social damage, and, vice versa, to assess whether the eradication or the neutralization of the antisocial individual would benefit the general population. Social psychiatrists were obliged to work out a list of diseases that categorized each mental condition according to its social usefulness or harmfulness. Thus social psychiatry was amalgamated with racial hygiene, and euthanasia came to be promoted as a therapeutic measure. Although the term social psychiatry was less widely used from the beginning of the 1930s, in 1931 Ernst Rüdin, professor of psychiatry in Munich and later head of the Institute for Racial Hygiene, ${ }^{24}$ defined social psychiatry in precisely these terms. According to him the effects of social psychiatry would benefit the population at large. He also underlined the practical importance of selection and racial hygiene. Looking for traces of social psychiatry in the work of Emil Kraepelin, ${ }^{25}$ Rüdin stated that Kraepelin had also taken a social psychiatric, indeed a psychiatric-racial hygienic approach ("sozialpsychiatrisch, ja psychiatrisch-rassenhygienisch"). ${ }^{26}$ Thus, Rüdin equated social psychiatry with racial hygiene. "Social psychiatry" was reduced to the concept of prevention based on biological interventions, such as sterilization. This process of alignment between social psychiatry and racial hygiene was ongoing throughout the 1920s and tended to make the terms interchangeable. Given this development and the change of the political situation in 1933 , it is not surprising that in the 1930s and 1940s the term social psychiatry lost its previous wide spectrum of connotations and was narrowed down to issues in line with National Socialist politics.

The 1920s also saw the emergence of a programme for the academic discipline "social psychiatry". In 1921 Julius Raecke from Frankfurt published some papers in which he outlined the academic profile of social psychiatry. By 1914 Raecke had already established some psychiatric centres of community care in Frankfurt. These institutions were designed to relieve the pressure of the chronic mentally ill on large asylums; yet Raecke also wanted to protect individual freedom. He referred to the control that the Ministry of Health exercised over psychopathic individuals, arguing that this surveillance would push the institutions of ambulant care towards undesirable instances of social control. ${ }^{27}$ Moreover, he attempted to create an academic profile of social psychiatry. Social psychiatry had to investigate all relations of the mentally ill to family, school, profession, law, art, science, poetry, religion, politics etc. This investigation had to consider both the effects of the external world on the mentally ill individuals, and vice versa the effects of

\footnotetext{
${ }^{23}$ Rehm, op. cit., note 20 above, p. 744.

${ }^{24}$ On Rüdin, see Matthias M Weber, Ernst Rüdin: Eine kritische Biographie, Berlin and New York, Springer, 1993; Volker Roelcke, 'Psychiatrische Wissenschaft im Kontext nationalsozialistischer Politik und "Euthanasie": zur Rolle von Ernst Rüdin und der Deutschen Forschungsanstalt/Kaiser-Wilhelm-Institut', in Doris Kaufmann (ed.), Geschichte der Kaiser-WilhelmGesellschaft im Nationalsozialismus:

Bestandsaufnahme und Perspektiven der Forschung, vol. 1, Göttingen, Wallstein, 2000, pp. 112-50.
}

\footnotetext{
${ }^{25}$ On Kraepelin's use of the notion "social”, see Eric J Engstrom, 'Eugenics and the professionalization of German psychiatry: the case of Emil Kraepelin', paper presented at the conference 'Psychiatry and Eugenics in the 19th and 20th Centuries: Switzerland in the European-American Context', Monte Verità, 17-22 Feb. 2002.

${ }^{26}$ Ernst Rüdin, 'Kraepelins sozialpsychiatrische Grundgedanken', Arch. Psychiatrie, 1931, 87: 75-86.

${ }^{27}$ Julius Raecke, 'Soziale Psychiatrie', Irrenpflege, 1921, 25: 35-9.
} 


\section{Social Psychiatry in Germany in the Twentieth Century}

the mentally ill on society. ${ }^{28}$ Raecke's use of the term social psychiatry took into account the social dimension of mental health and illness as well as the academic profile of this newly emerging sub-discipline and the establishment of models of ambulant psychiatric care; in this respect his vision anticipated modern concepts of social psychiatry. Yet his ideas from the early 1920s did not materialize; instead the contents of racial hygiene were interlaced with those of social psychiatry.

In the years immediately after 1945 the term "social psychiatry" was not used. Even when in the 1950s several models of occupational therapy and housing were discussed and put into practice in the German Democratic Republic, the term "social psychiatry" could not be found in contemporary papers. Despite the fact that psychiatrists referred to specific historical examples, they preferred the terms "Resozialisierung" and "Rehabilitation" (rehabilitation) in order to describe their endeavours. ${ }^{29}$ In the Federal Republic of Germany "Sozialpsychiatrie" was used again in the 1950s in a double sense: first, it was connected to a socio-philosophical reflection on the relationship between the individual and society, viewing the individual as an integrated social human being. It was in this context that the relationship of psychiatric care and preventive psychiatry was also debated. In 1958 a book entitled Psychiatrie und Gesellschaft was published that dealt with the relationship between psychiatry and society. ${ }^{30}$ It covered a large range of topics. There were references to social psychiatry and the mental health movement of the USA, ${ }^{31}$ as well as general reflections on abnormal behaviour. ${ }^{32}$ Other articles addressed the importance and limitations of mental hygiene and psychotherapy, ${ }^{33}$ the relationship between child psychiatry and pedagogy, ${ }^{34}$ and contacts between criminology and psychiatry. ${ }^{35}$ Further chapters considered "asylum psychiatry and ambulant psychiatric care" 36 as well as active therapy and rehabilitation of schizophrenics. ${ }^{37}$ The chapter on asylum psychiatry and ambulant psychiatric care referred to historical models from the 1920 s and maintained that it was necessary to integrate the mentally ill into "normal" social conditions. The article also mentioned the urgent problem of overcrowded hospitals for the mentally ill and called for patients to be discharged as early as possible in order to relieve the pressure. The author expressed his satisfaction that after 1945 some fifty-four psychiatric hospitals in West Germany had made provision for ambulant psychiatric pre- and after-care. ${ }^{38}$ The various articles of the book illustrate that in the second half of the 1950s the concept of social psychiatry represented a crucial option for a considerable number of German psychiatrists. Certainly, the concept of social psychiatry

\footnotetext{
${ }^{28}$ Julius Raecke, 'Soziale Psychiatrie', Psychiatr. Neurol. Wochenschr., 1921/22, 24: 116-19.

${ }^{29}$ See, for example, Friedrich Rudolf Groß, ‘Über die Widerstände gegen die Rehabilitation psychisch Kranker', Das deutsche Gesundheitswesen, 1962, 17: 1766-75.

${ }^{30} \mathrm{H}$ Erhardt, D Ploog, H Stutte (eds), Psychiatrie und Gesellschaft. Ergebnisse und Probleme der Sozialpsychiatrie, Bern and Stuttgart, Hans Huber, 1958.

${ }^{31}$ G S Stevenson, L B Kalinowsky, 'Psychische Hygiene in den USA', in ibid., pp. 167-74.

${ }^{32} \mathrm{H}$ Kranz 'Über neuzeitlich-epochale Bedingtheiten des psychisch Abnormen', in ibid., pp. 33-41.
}

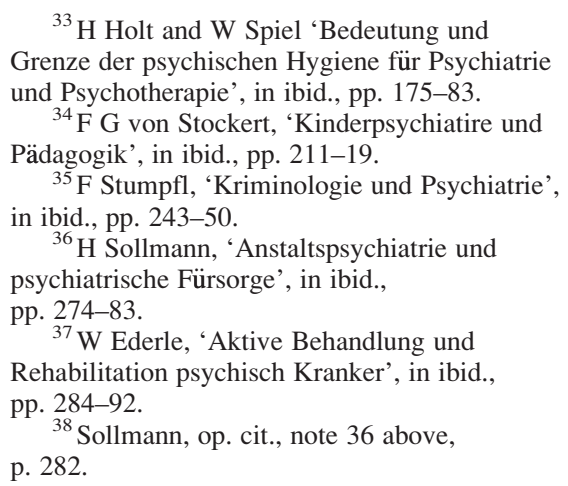




\section{Heinz-Peter Schmiedebach and Stefan Priebe}

was used in a very unspecific sense, without a concrete, commonly accepted definition; the phase of the late 1950s and early 1960s could be described as a period of orientation and research.

In the course of the 1960s and 1970s debates about social psychiatry in the German Democratic Republic as well as in the Federal Republic were given fresh and very impressive impetus. This led to the ten theses of Rodewisch (GDR), formulated in 1963, and to a very active reform movement in West Germany around 1970. Over the last thirty years the term "social psychiatry" has been given more distinctive contours. As Priebe and Finzen have pointed out, it has come to mean "firstly, an area of theoretical and empirical science; secondly, a political movement; and, thirdly, a way to practice mental health care." 39 These three connotations are valid to this day, yet sometimes one or two of the three stand in the foreground whilst the others are of minor importance, or are not taken into consideration. Thus, despite the fact that these three connotations are widespread and in common use, the possibility for semantic confusion continues to exist, so that a good understanding of the culture and context in which the term is used is also essential, as Priebe and Finzen pointed out. By contrast with the historical meanings in early twentieth-century Germany, when aspects of medical and socio-political surveillance, or racial hygiene were connotative parts of the concept, the modern term is more concerned with scientific requirements, emancipatory options regarding the patients, and community-oriented psychiatric care.

\section{Early Models of Extramural Psychiatric Care in Germany}

Family care is the oldest system of extramural psychiatric care. In the nineteenth century the family care system practised in Scotland served as a model for Germany ${ }^{40}$ where it was discussed intensively between 1860 and $1870 .{ }^{41}$ In the second half of the nineteenth century some asylums made the first attempts to establish institutions of family care. They did so primarily to alleviate problems of overcrowding and because the costs of family care were relatively low compared with those of a hospital. Family care was not seen as a rehabilitative bridge between the asylum and independent accommodation outside, but rather as terminal housing for the able and non-violent mentally ill. ${ }^{42}$ Wilhelm Sander, the first director of the newly opened Dalldorf asylum in Berlin in 1880, was very involved in the establishment of family care. Between 1893 and 1897 this asylum transferred 1,102 patients from the hospital to families; 48.3 per cent found accommodation within their own extended families, 51.7 per cent were placed in foster families. Of the patients in family care, 36 per cent had to be readmitted to the asylum, and 6 per cent had to be transferred to other asylums. ${ }^{43}$

\footnotetext{
${ }^{39}$ Priebe and Finzen, op. cit., note 2 above, pp. 47-9.

${ }^{40}$ Friedrich Jolly, 'Ueber familiale Irrenpflege in Schottland', Arch. Psychiatr. Nervenkrankheiten, 1875, 5: 164-88.

${ }^{41}$ Paul-Otto Schmidt, Asylierung oder familiale Versorgung. Die Vorträge auf der Sektion Psychiatrie der Gesellschaft Deutscher Naturforscher und Ärzte bis 1885, Husum, Matthiesen, 1982; Thomas Beddies and Heinz-Peter Schmiedebach, 'Die Diskussion um die ärztlich
}

beaufsichtigte Familienpflege in Deutschland', Sudhoffs Archiv, 2001, 85: 82-107.

${ }^{42}$ Heinz-Peter Schmiedebach, Thomas Beddies, Jörg Schulz, Stefan Priebe, 'Housing and work as criteria of the "social integration" of the mentally ill-development in Germany between 1900 and 2000', Psychiatr. Praxis, 2002, 29: 285-94.

${ }^{43}$ Emil Nawratzki, 'Über Ziele und Erfolge der Familienpflege Geisteskranker nebst Vorschlägen für eine Abänderung des bisher in Berlin angewendeten Systems'. Allg. Z. Psychiatrie, 1902, 59: 411-36. 


\section{Social Psychiatry in Germany in the Twentieth Century}

In the first half of the twentieth century Gustav Kolb in Erlangen and Friedrich Wendenburg in Gelsenkirchen developed two different systems of open psychiatric care which signified more than a simple transfer of the mentally ill from asylum to families. Despite significant structural differences between the systems, they both attempted to expand the influence of psychiatrists over the population at large. They endeavoured to improve mental health by establishing a comprehensive network of institutions which were obliged to register and control suspect families. A comparison of the two systems can be made by examining the following questions: what role did the asylum play within these systems of extramural care? What type of relationship existed between psychiatric care and other care-based community institutions? And why did psychiatrists propose these systems?

By 1903 Kolb had already outlined his programme and in 1908 he began to establish his asylum-centred system of open psychiatric care in Erlangen, Bavaria. The asylum functioned as the main pillar of his system, which had to provide extramural work and after-care. He established psychiatric care-centres outside the asylum; yet, the medical staff of the mental hospital had to run these centres and be available for consultation (stationäre Fürsorge); and they were also obliged to visit the patients at home (nachgehende Fürsorge). ${ }^{44}$ Kolb was convinced that asylum care and extramural psychiatric care were two inseparable and complementary parts of one single system of mental health care. Although he strongly recommended close collaboration with community welfare centres (Wohlfahrtsämter) and public health offices (Gesundheitsämter), he also underlined the important role of asylum staff. Their psychiatric experience and affiliation with mental hospitals made them the only professionals competent to run the system of mental hygiene. With this argument he attempted to enhance the professional power of psychiatrists. Yet he also referred to a cost-benefit analysis, and suggested that this kind of open psychiatric care was "natural progress" because it enabled mental health care to achieve a maximum of efficacy with a minimum of expenditure. Kolb argued that it was highly necessary to establish an open care system because of the limited space in existing mental hospitals and because impoverishment had prevented the extension of mental health care within asylums. ${ }^{45}$ He described the tasks of the open care system as socio-medical (sozial-medizinisch) tasks and as essentially social, but achievable only with the help of psychiatric knowledge. In order to reduce expenditure, the open care system would keep the mentally ill and abnormal people out of the asylums and reject unjustified claims of mentally inferior (geistig Minderwertigen) and psychopathic persons, while continuing to exercise a certain amount of control over them. ${ }^{46}$

Kolb outlined five specific tasks: first, the reintegration of discharged mentally ill patients with their families and occupations, thus eliminating the disadvantages and dangers they posed for the general public; second, the scientific, statistical and socio-medical registration of all mentally ill and abnormal people outside the asylums; third, the consolidation of all local asylums and other caring institutions according to psychiatric

\footnotetext{
${ }^{44}$ Gustav Kolb, 'Die offene psychiatrische Fürsorge', in O Bumke, G Kolb, H Roemer, E Kahn (eds), Handwörterbuch der psychischen Hygiene und der psychiatrischen
}

Fürsorge, Berlin and Leipzig, De Gruyter, 1931, pp. 117-20.

$$
\begin{aligned}
& { }^{45} \text { Ibid., p. } 118 . \\
& \text { Ibid. }
\end{aligned}
$$




\section{Heinz-Peter Schmiedebach and Stefan Priebe}

principles; fourth, the publication of psychiatric knowledge and experience of the mentally ill living outside the asylums; fifth, the publication of knowledge about mental hygiene in order to prepare for preventive intervention. He emphasized that the extramural care had lasting effects complementing the treatment that the mentally ill received in the asylum and repeatedly referred to the positive economic advantages for the nation of his system of open care, given its lower building and maintenance costs. ${ }^{47}$

Kolb's model exhibited certain ambiguities: on the one hand it guaranteed that a large number of people could stay outside the asylum, thus enhancing the degree of freedom and social integration allowed to the mentally ill. On the other hand, however, this newly acquired freedom was, paradoxically, inseparably connected to an increase in the power of the asylum's doctors outside the institution. His model opened the way for medical surveillance of families, especially those with mentally ill relatives. The doctors could familiarize themselves with the family situation and, in particular, acquire the insight into hereditary conditions that they needed for preventive sterilization. This open care model did not necessarily lead to a stronger and more independent role for patients, but rather to a more influential role and improved status for psychiatrists. The expanding socio-political activities of psychiatrists were based on newly developed methods of social hygiene and social science, such as epidemiologic registration, statistics and public intervention. Hence this new phase of professional expansion was connected to the use of new scientific methods in psychiatric research. Alongside the somatic and hereditary foundation of the academic discipline "psychiatry" during the second half of the nineteenth century, the early twentieth century saw an integration of modern social science research skills into psychiatry. Nevertheless, psychiatry remained within the scope of medical science; it did not reject its anatomical and physiological foundations which were crucial to its former academic promotion, and it benefited from the high reputation which the general public awarded to medicine and medical science.

The second model was developed by Wendenburg in the early 1920s. Unlike that of Kolb, Wendeburg's psychiatric open care system was organized by community welfare centres and public health offices. The asylum was not the centre, but simply one part within the network of institutions. Psychiatric open care was only a branch of the health care activities of communities, alongside care for other patients with tuberculosis, or for the handicapped. Wendenburg viewed this community oriented network as advantageous because of the opportunity it provided for comprehensive registration and for the far-reaching application of experiences collected from all the integrated branches of community health care. ${ }^{48}$ Like Kolb, he stressed the economic benefits of his system, believing that early registration of individuals and the application of preventive measures would lower the costs of mental health care.

Wendenburg's system consisted of an early registration, preventive consultation before the outbreak of the disease in individuals of socially deviant families, periodic inspections, development and implementation of an effective treatment plan. As opposed to the tasks formulated by Kolb, Wendenburg put more emphasis on the administrative

\footnotetext{
${ }^{47}$ Ibid., p. 120.

${ }^{48}$ Friedrich Wendenburg, 'Offene Fürsorge vom kommunalen Fürsorgeamte aus', in Bumke, Kolb, 


\section{Social Psychiatry in Germany in the Twentieth Century}

and socio-political mastery of mental illness and abnormal behaviour. He recommended six specific tasks, beginning with the registration of all the individuals in question. In order to act on as large a part of the population as possible, he recommended drawing on the resources of the existing system of community family care which was part of the social care system. In this way families with epileptics, backward children (Hilfsschüler), recalcitrant children, psychopaths, etc., could be observed and it would be easy to detect those mentally ill and abnormal individuals who had to be registered. Second, the handling of the whole procedure of admission to an asylum could be accelerated by a community care centre. Because of the centralized and simplified technical administrative procedures, an individual could be admitted to an asylum within a few hours; it would be easy to organize the papers needed for admission, for example, police consent forms or declarations on the reimbursement of costs. He saw this accelerated procedure as an important means of avoiding harmful and incorrect treatment. ${ }^{49}$ Third, the system had to prepare the discharge of patients and organize their after-care. The community care centre would help to organize the discharge as early as possible and to foster the reintegration of the mentally ill with their families and occupations by counselling relatives and colleagues. The psychiatric care centre would work together with other institutions of community care, such as employment centres (Arbeitsamt) and housing offices (Wohnungsamt) in order to provide work and accommodation for the discharged person. Well prepared extramural support of the mentally ill would lead to an improvement of mental health and to a restoration of the ability to work. Fourth, the psychiatric care centre had to maintain close contact with the asylum and with the relatives in order to organize visits, temporary leave, or early discharge. Hence, the care centre needed to be informed about all social contacts between the mentally ill and the families, and served as an intermediary between the asylum's doctor and the social milieu of the patient. Fifth, the staff of the centre had to advise and to influence the relatives. This influence would attempt to produce a "correct mental attitude" (richtige Einstellung) toward the mentally ill and asylum treatment. These activities went beyond the mere mental health of the individual, and touched on questions of medical internment, divorce, preventive detention, and other forensic issues. According to Wendenburg, it was much easier for the community care centres to establish close ties with police, jails, and prosecution lawyers. He referred to a particular example of some jails that reported the names of discharged persons with symptoms of mental abnormity to the community psychiatric care centres. Sixth, the psychiatric care centre had to control and supervise the discharged patients living outside the asylums. Wendenburg called for continuous medical surveillance of these patients and their families. The staff of the community care centres included doctors, nurses and social workers. He considered the staff very well suited for the task of inconspicuous visits to the homes or workplaces of the people under surveillance. $^{50}$

Wendenburg promoted a psychiatric open care system which was an integral part of a community network that consisted of different care institutions, such as family care, psychiatric care, and care for people suffering from tuberculosis, etc. This network

${ }^{49}$ Ibid., p. 135.

${ }^{50}$ Ibid., p. 136. 


\section{Heinz-Peter Schmiedebach and Stefan Priebe}

could provide highly effective contacts and draw on well functioning communication facilities within a single community care structure with a rich variety of specialized care branches. Of course, the staff that worked in the centres for the mentally ill had to be trained in psychiatry. The responsible physician would be qualified in psychiatry, and ideally be a doctor of the asylum, even though the asylum's physicians lacked the time to perform these duties. Wendenburg welcomed rules requiring female family care workers to complete a three-month training period in a psychiatric hospital. Compared to Kolb's concept, the asylum was not the only centre of the care system, although Wendenburg viewed the mental hospital as the first instance of psychiatric treatment. Kolb's monocentred concept envisaged the asylum as the only centre that organized both intra- and extramural care. In contrast to Kolb, Wendenburg planned two institutional centres that would work in close collaboration: on the one hand all sections of the community care system, including psychiatric care, and, on the other, the asylum. Each of the two institutions had an independent organization, but they had to collaborate closely in a coordinated way. Ideally a psychiatrist should work in both institutions, which in reality did not happen. Wendenburg called for the accelerated admission of endangered persons to the asylums and, because he considered the comprehensive community care system well suited for that purpose, he argued for his more community based system. Wendenburg's system of open psychiatric care facilitated the admission of mentally ill or abnormal people to closed hospitals. Apart from that, his system showed greater commitment to forensic, public security, and judicial issues than Kolb's system.

Although both Kolb and Wendenburg encouraged medical surveillance, and buttressed their arguments with cost-benefit analyses, both systems had another effect which must be taken into consideration: they expanded psychiatry from the closed asylums where its activities were concealed; and with the new systems of open care, psychiatry partly opened its practice to the eyes of the general public. This path toward more transparent psychiatric care was in part a response to what contemporary psychiatrists came to call an anti-psychiatry movement. This movement, which emerged in the late $1880 \mathrm{~s}$, mirrored the dismal public image of psychiatry and the public mistrust of carceral practices. $^{51}$ Over the years it gradually intensified its critique of academic and asylum psychiatrists and was ultimately able to mobilize not only the press but also to instigate parliamentary debates in several German parliaments and the Reichstag. ${ }^{52}$ These debates revolved around issues of arbitrary internment and illegal detention in psychiatric asylums. The psychiatric profession's response to this public criticism was mixed. On the one hand, it sought to defend itself and refute the charges advanced against it; ${ }^{53}$ on the other it was eager to demonstrate how dissimilar asylums were to prisons. In this context

\footnotetext{
${ }^{51}$ Heinz-Peter Schmiedebach, 'Eine "antipsychiatrische" Bewegung um die Jahrhundertwende', in Martin Dinges (ed.), Medizinkritische Bewegungen im Deutschen Reich (ca. 1870- ca. 1933), Stuttgart, Steiner, 1996, pp. 127-59.

${ }_{52}$ Ann Goldberg, 'The Mellage trial and the politics of insane asylums in Wilhelmine Germany',

J. mod. Hist., 2002, 74: 1-32.
}

\author{
${ }^{53}$ Thomas-Peter Schindler, 'Psychiatrie \\ im Wilhelmischen Deutschland im Spiegel \\ der Verhandlungen des "Vereins der deutschen \\ Irrenärzte" (ab 1903: "Deutscher Verein für \\ Psychiatrie”) von 1891-1914', Diss. med., \\ Freie Universität Berlin, 1990, \\ pp. 142-3.
}




\section{Social Psychiatry in Germany in the Twentieth Century}

some psychiatrists argued that the psychiatric training of medical students on the psychiatric wards of university hospitals was a form of public control of psychiatric hospitals. The presence of students would reduce public mistrust of psychiatric institutions. ${ }^{54}$ In 1931 the social psychiatrist Paul Nitsche spoke of the "carceral spirit" pervading asylums and of an undesirable dependence of patients on their doctors. Because this troubled the general public it was necessary to make treatment as open as possible. ${ }^{55}$ In order to address such concerns the asylums had already established wards with various degrees of seclusion, from the very secluded observation wards (Wachstation) to the open wards and agricultural colonies outside the asylum where the mentally ill lived in open houses. The psychiatric open care system had the great advantage of facilitating the control of patients and mentally abnormal persons to a certain degree without giving them the feeling of being under the total surveillance of the doctors. ${ }^{56}$

Kolb's asylum-centred system satisfied these requirements especially well. All the institutions involved were affiliated to the hub, so that everyone who came into contact with the open care system was also in contact with the asylum. A structure was formed that was partially transparent to the general public, and conversely paved the way for doctors to move out from behind the walls of the asylum towards society at large. The establishment of this open care system directly linked the reduction of public mistrust to the extended influence of psychiatrists on families and patients living outside the institutional realm of psychiatry. Thus, this move can be viewed as a professional strategy that aimed to secure psychiatric jurisdiction over all manner of social issues. As early as the 1870 s, alongside the process of academic institutionalization at the German universities, psychiatrists had attempted to offer their services to society, claiming that their professional knowledge would solve social problems. At the beginning of the twentieth century they intensified their endeavours, partly driven by some very pragmatic problems, such as overcrowding in the asylums, financial constraints, and public mistrust of custodial psychiatry. These problems drove psychiatrists into action, prompting them to extend the field of psychiatric professional competence and to put their expertise at the disposal of German society and the state.

In 1923 Hermann Simon published his first article in which he outlined the concept of "active therapy". He intended to overcome the generally poor conditions and arrangements within the asylums which negatively influenced the inmates and caused additional pathological symptoms of anti-social behaviour. In order to overcome the detrimental consequences of staying in an asylum, Simon promoted occupational therapy connected with the delegation of responsibility to the patients. The inmates had to work and be responsible for the results of their work and activities. Thus the patients should take an active part in their own recovery. Although Simon initially aimed only at improving the non-therapeutic conditions in the asylums, his concept fitted very well into the open care

\footnotetext{
${ }^{54}$ See Heinz-Peter Schmiedebach, 'Die Herausbildung der Neurologie in Greifswald-Anmerkungen zur Fächerdifferenzierung in der Medizin', in Wolfgang Fischer and Heinz-Peter Schmiedebach (eds) Die Greifswalder Universitäts-Nervenklinik unter dem Direktorat von
}

Hanns Schwarz 1946 bis 1965, Greifswald, Ernst-Moritz-Arndt-Universität, 1999, pp. 98-114.

${ }^{55}$ Paul Nitsche, 'Die Behandlung in der Heilanstalt', in Bumke, Kolb, Roemer, Kahn (eds), op. cit., note 44 above, pp. 98-105.

${ }^{56}$ Ibid., p. 104. 


\section{Heinz-Peter Schmiedebach and Stefan Priebe}

model, the success of which depended on the active and responsible behaviour of the mentally ill individual. At the end of the 1920s Simon himself discussed his model in the wider context of social psychiatry. He maintained that this kind of therapy fostered the adjustment of the patient to the social environment, which was a prerequisite for any successful struggle for survival. It would enhance patients' energy, their capacity of resistance, tenacity and attention, as well as their self-esteem and responsibility. By continuously working on themselves, patients would be able to achieve higher efficiency and to become useful members of society. Thus, psychiatric occupational therapy would lead to a reduction of costs and at the same time enhance people's performance. ${ }^{57}$ Psychiatry offered its services in order to create better and more efficient mentally ill workers by applying its rational modern therapeutic methods. Emil Kraepelin ${ }^{58}$ went one step further and defined another new field of psychiatric competence. In doing so he opened the door for a rational utilization of human resources based on psychiatric expertise. The psychiatrist was supposed to have the responsibility for defining the standards of mental and physical abilities needed for social and professional tasks in society. Having defined such standards, doctors could use them to evaluate the whole population. They could be applied to such characteristics as suitability for military services, aptness for school requirements, soundness of mind, and legal capacity. ${ }^{59}$ Such claims took psychiatry beyond its traditional tasks and sought to secure for the profession a role in the distribution of human resources. All the reported examples underline psychiatrists' tendency to expand their competence to all social fields. The models of open psychiatric care described above fit very well into this general endeavour of the profession. The two models aimed at a registration of mental illness and an evaluation of the epidemiological characteristics of mental disturbances in society in order to develop sufficient means of prevention; moreover, they sought cheap accommodation and thorough integration of patients into work-processes. Taken together, all of these tasks reflect a comprehensive programme of social management of mental illness that held out the prospect of lower costs, effective control, as well as early diagnosis and prevention. The individual's preferences were not taken into account and the freedom conceded to patients outside the asylums was more a product of institutional needs than of any respect for the human rights of the mentally ill. Mentally ill individuals were assessed only with reference to their constantly redefined usefulness or burdensomeness to the state and society. As early as the First World War, and much more so in National Socialist Germany, the social status of the mentally ill worsened considerably, and the ability to work became an obligation for patients and, in the Third Reich, a criterion for selection that determined whether they would live or die.

Between 1939 and 1945 psychiatrists in Germany participated in the largest systematic programme to kill patients known in the history of medicine. According to recent

\footnotetext{
${ }^{57}$ Hermann Simon, 'Beschäftigungsbehandlung', in ibid., pp. 108-13.

${ }^{58}$ On Kraepelin and his attitude toward social questions, see Engstrom op. cit., note 25 above.
} 


\section{Social Psychiatry in Germany in the Twentieth Century}

estimates, a total of 260,000 patients suffering from mental illnesses and mental retardation were murdered. ${ }^{60}$ Some of the psychiatrists who participated in the programme had been advocates of mental health care reforms in pre-national socialistic times, for example Valentin Faltlhauser, who had a reputation as a protagonist for open care, ${ }^{61}$ and Carl Schneider, professor of psychiatry at Heidelberg University, who had written extensively on social aspects of psychiatry and developed a detailed theory of work and occupational therapy. ${ }^{62}$ Several explanations of their motives have been discussed, such as Faltlhauser's desire to end the patients' torment of their disease and his own torment of therapeutic helplessness. ${ }^{63}$ Other factors considered include, in the case of Schneider, a general support for the ideology of the NS regime and the desire to conduct research on the victims. ${ }^{64}$ In the second half of the 1930s, psychiatry's activities had to follow the programme of National Socialist health policies. A central component of open care as developed in the 1920s had been directed at care in and for the community. This was now redefined as oriented towards the interests of the German people, nation and race and, as such, turned against the patients.

\section{Post-War Psychiatry and the Reform Movements of the 1960s and 1970s}

In the early years after 1945 social psychiatric issues played only a minor role in Germany. There were several reasons for this. Because hundreds of thousands of patients had been killed by doctors and nursing staff in National Socialist Germany and because of the transformation of a large number of asylums into military hospitals, there were no urgent needs for the development of new forms of open psychiatric care. Moreover, just as in prewar times the surviving mentally ill stood at the bottom of the social hierarchy, as a result of acute food shortages after 1945 many of the asylum inmates who had survived the war subsequently died of starvation. ${ }^{65}$

In the 1950s the first papers dealing with social psychiatric themes were published by psychiatrists of the German Democratic Republic. In 1952 Dietfried Müller-Hegemann underlined the importance of work as a crucial means of rehabilitation. ${ }^{66}$ Liselotte Eichler followed a few years later with a paper on occupational therapy, which was

\footnotetext{
${ }^{60}$ Schmuhl, op. cit., note 5 above, p. 297.

${ }^{61} \mathrm{U}$ Pötzl, Sozialpsychiatrie, Erbbiologie und Lebensvernichtung: Valentin Faltlhauser, Direktor der Heil- und Pflegeanstalt Kaufbeuren-Irsee in der Zeit des Nationalsozialismus, Husum, Matthiesen, 1995.

${ }^{62}$ Carl Schneider, Behandlung und Verhütung der Geisteskrankheiten. Allgemeine Erfahrungen, Grundsätze, Technik, Biologie, Berlin, Julius Springer, 1939.

${ }^{63}$ See Pötzl, op. cit., note 61 above.

${ }^{64} \mathrm{C}$ Teller, 'Carl Schneider. Zur Biographie eines deutschen Wissenschaftlers', Geschichte und
}

Gesellschaft, 1990, 16: 464-78; Klaus Dörner, 'Carl Schneider: Genialer Therapeut, moderner ökologischer Systemtheoretiker und Euthanasie-Mörder. Zu Carl Schneiders "Behandlung und Verhütung der Geisteskrankheiten', Berlin, Springer 1939', Psychiatr. Praxis, 1986, 13: 112-14.

${ }^{65}$ Heinz Faulstich, Hungersterben in der Psychiatrie 1914-1949. Mit einer Topographie der NS-Psychiatrie, Freiburg/Br., Lambertus, 1998.

${ }^{66}$ Dietfried Müller-Hegemann, 'Die Bedeutung der Arbeitstherapie in der Gegenwart', Psychiatr. Neurol. Med. Psychologie, 1952, 4: 97-101. 


\section{Heinz-Peter Schmiedebach and Stefan Priebe}

designed to provide the mentally ill with regular employment contracts as early as possible. ${ }^{67}$ The mental hospital was the main institution from which all activities of psychiatric rehabilitation started. In order to facilitate the transition from the asylum to regular work, psychiatrists encouraged protected places of employment, places with reduced working hours for the mentally ill, and factories with courses for retraining. The psychiatrists of the GDR also addressed the problem of housing and referred in this context to examples and models taken from foreign countries, among them the United Kingdom. ${ }^{68}$

Around 1950 family care was considered an accepted kind of open psychiatric care. ${ }^{69}$ Yet only a few years later it fell into disrepute. This rejection arose out of two considerations: first, according to socialist ideology, the family was not seen as a promising social model; second, the mentally ill who lived with the families of craftsmen often had to work in the small craftsman's firm and this came to be viewed as a kind of unjustified exploitation of the patient, incompatible with the principles of a socialist society. ${ }^{70}$

In 1963 an international symposium on psychiatric rehabilitation ${ }^{71}$ held in Rodewisch (GDR) identified the most important of all psychiatric activities as the re-integration of individuals into active, free and responsible lives. ${ }^{72}$ Although the declaration that was passed by the participants of the Rodewisch conference primarily stressed the development of open psychiatric hospitals, the authors also endorsed the establishment of an after-care system run by a collective of psychiatrists, psychologists and female welfare social workers (Fürsogerinnen). In addition, the paper called for the establishment of protected workshops affiliated with hospitals, special hostels for patients, and psychiatric day- and night-clinics. In 1967 the East German psychiatrist $\mathrm{H}$ Ulbricht defined rehabilitation as the main aim of psychiatry and called for the integration of patients into the regular working world. ${ }^{73}$ The different models of protected work were soon ensconced in law so that it became possible to provide the mentally ill with graduated work agreements, such as for rehabilitative work or occupational therapy, without fully valid contracts of employment. ${ }^{74}$ In the early 1960 s in Mühlhausen/Thuringia a special hostel for long-term or chronic patients was established as a modified night-clinic in order to facilitate the transmission from hospital to society. Of the 56 patients, 45 were found a place of employment outside the hospital and 12 of these were discharged. Because of these very positive results, the psychiatrists

\footnotetext{
${ }^{67}$ Liselotte Eichler, 'Arbeitstherapie und

Wiedereingliederung in die Arbeit von Standpunkt des Psychiaters', Das deutsche Gesundheitswesen, 1957, 12: $1-8$.

${ }^{68}$ See Joshua Bierer, 'Eine Revolution in der Psychiatrie Großbritanniens', Das deutsche Gesundheitswesen, 1960, 15: 645-50.

${ }^{69} \mathrm{R}$ Lische, 'Die Aufgaben der psychiatrischen Fürsorge', Das deutsche Gesundheitswesen, 1953, 8: $625-31$.

${ }^{70}$ Eichler, op. cit., note 67 above, p. 7.

${ }^{71}$ Heinz-Peter Schmiedebach, Thomas Beddies, Jörg Schulz, Stefan Priebe, 'Offene
}

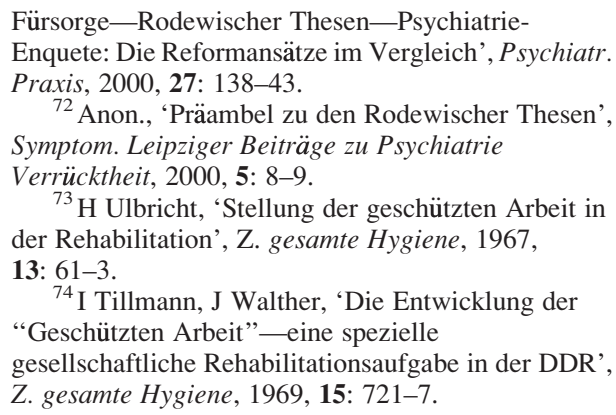

${ }^{73} \mathrm{H}$ Ulbricht, 'Stellung der geschützten Arbeit in der Rehabilitation', Z. gesamte Hygiene, 1967, 13: $61-3$.

${ }^{74}$ I Tillmann, J Walther, 'Die Entwicklung der "Geschützten Arbeit"—eine spezielle gesellschaftliche Rehabilitationsaufgabe in der DDR', Z. gesamte Hygiene, 1969, 15: 721-7. 


\section{Social Psychiatry in Germany in the Twentieth Century}

E Lange and U Bergmann called for the Thuringian model to be implemented systematically throughout the GDR. ${ }^{75}$ It is difficult to write a comprehensive account of the situation in the GDR; although a number of papers have been published on this topic, they provide us with only very cursory information. Yet in the 1970s there was sporadic criticism of rehabilitation for its reputed neglect of the personality of the patient and its emphasis on simply providing a place of employment. ${ }^{76}$ However, even securing those places was not easy; sometimes the firms dismissed mentally ill workers, or annulled the contracts. Historical accounts of the development of psychiatry in the former GDR distinguish between three periods: 1961 to 1970 was a time of awakening and confidence; this was followed by a period of resignation and subordination; before finally in the last years of the German Democratic Republic psychiatrists and patients received a little more freedom. ${ }^{77}$ The impression remains that only a relatively small circle of psychiatrists were involved in this reformist engagement. An open discussion of the social psychiatric problems of housing and occupation among all the concerned and interested people in medicine and society did not take place and the reform-oriented psychiatrists had no discernible social impact.

In the Federal Republic of Germany social psychiatric issues began to be discussed in the $1950 \mathrm{~s}^{78}$ Yet it was not until the early 1960s that the discussion widened in scope $^{79}$ taking account of traditional models of the 1920s as well as the contemporary situation in foreign countries, particularly in Great Britain, where in 1959 the Mental Health Act was enacted and other moves towards de-institutionalization started. ${ }^{80}$ At the same time, the first models of extramural care emerged. In 1956 the German Red Cross started to run an open hostel where the discharged mentally ill could live and become re-socialized. In 1959 a psychiatric night-clinic in Frankfurt was opened for the mentally ill, followed a few years later by a day-hospital. ${ }^{81}$ Other pioneering socialpsychiatric institutions were established in 1968 in Heidelberg, Hanover and Gießen. ${ }^{82}$ Until the end of the 1960s these initiatives remained the isolated activities of particularly committed psychiatrists. Facilitated by the socio-political movement and student rebellion of the late 1960s, especially demands for civil rights, social reform, as well as emancipation and equal rights for social and political minorities, the early 1970s

\footnotetext{
${ }^{75}$ E Lange, U Bergmann, 'Die rehabilitative und ökonomische Bedeutung der "befürsorgten

Wohnstätte" als eine Sonderform der psychiatrischen

Nachtklinik', Das deutsche Gesundheitswesen, 1966, 21: 1130-34.

${ }^{76}$ M Kreyßig, 'Psychologische und ethische Probleme der Rehabilitation psychisch Kranker', Psychiatr. Neurol. Med. Psychologie, 1978, 30: 657-64.

${ }^{77}$ See Loos, op. cit., note 3 above, pp. 174-80.

${ }^{78}$ See, for example, the book by Erhardt, Ploog and Stutte, op. cit., note 30 above.

${ }^{79} \mathrm{H}$ E Schulz, 'Über psychiatrische Außenfürsorge', Nervenarzt, 1962, 6: 494-501; $\mathrm{H}$ Viefhues, 'Fürsorge für psychisch Kranke durch ein
}

psychiatrisches Fürsorgezentrum', Der öffentliche Gesundheitsdienst, 1963, 25: 486-93.

${ }^{80} \mathrm{~L}$ Clarke, 'The opening of doors in British mental hospitals in the 1950s', Hist. Psychiatry, 1993, 4: 527-51.

${ }^{81}$ See C Kulenkampff, 'Über die psychiatrische Nachtklinik', Nervenarzt, 1961, 5: 217-22; also $\mathrm{G}$ Bosch, 'Zur Indikation tageklinischer Behandlung', Nervenarzt, 1971, 42: 457-66.

${ }^{82}$ Klaus Dörner and U Ploog, Anfänge der Sozialpsychiatrie. Bericht über eine Reise durch die sozialpsychiatrischen Pioniereinrichtungen der Bundesrepublik im Jahre 1968. Ein psychiatriehistorisches Dokument, Bonn, Edition Das Narrenschiff, 1999, pp. 23-8. 
presented numerous activities concerning social psychiatric issues. In 1971 the German Bundestag was urged to establish a commission to evaluate the state of psychiatric care in the Federal Republic of Germany. The growing influence of the mass media and reports of deleterious living conditions within the asylums had forced the government's hand. Without this socio-political movement and media pressure, ${ }^{83}$ psychiatrists who in the mid-1960s had criticized the poor conditions within the asylums ${ }^{84}$ would not have had such a far-reaching impact. Four years later the commission published the so called Psychiatrie-Enquete and proposed a comprehensive programme for a reform of psychiatric care. The report and its suggestions were unanimously endorsed by all parties in the German Bundestag. The suggestions were similar to those produced at the Rodewisch symposium of 1963. For example, the commission recommended a care system in which mental and physical illness or acute and chronic patients were given equal access to treatment; it also recommended that long-term hospitalization be avoided and that patients be guaranteed continuous psychiatric services through a single closely connected "therapeutic chain" spanning all the services and institutions at a community level. It was also intended that self-help organizations of patients and relatives should be integrated into this community-based network of professionals and laymen. ${ }^{85}$ The aim of this reform was not just an improvement in patient care and cure, but rather an increase in the numbers restored to health among the mentally ill.

Based on the suggestions of the Psychiatrie-Enquete, a rich variety of decentralized, community-oriented institutions providing new forms of housing and work emerged throughout West Germany in the following years. The traditional family care system was resuscitated, ${ }^{86}$ and specific models were developed to structure the working conditions of the mentally ill. One of these models was the so called "Patientenkollegenmodell" (Patients-colleagues-model) in which former patients worked under regular working conditions on the basis of regular contracts. The colleagues of these former patients were informed about the situation of their new co-workers and agreed to make allowances for them and treat them with respect. About half of the group of the former patients working under these conditions was able to remain employed for more than five years. ${ }^{87}$ This model did not require a one-sided adjustment of the mentally ill to working conditions and colleagues, but was rooted in the readiness of healthy people to

\footnotetext{
${ }^{83}$ See Peter Treppner, “"Der Gesundheitsnotstand Nr. 1"- - die Psychiatrie der 70er Jahre in den Printund elektonischen Massenmedien an ausgesuchten Beispielen', Diss. med., Universität Greifswald, 1996.

${ }^{84}$ Heinz Häfner, Walter von Balyer, Karl-Peter Kisker, 'Dringliche Reformen in der psychiatrischen Krankenversorgung der Bundesrepublik', Helfen und Heilen, 1965, 4: 1-8.

${ }^{85}$ Bericht über die Lage der Psychiatrie in der Bundesrepublic Deutschland: zur psychiatrischen und psychotherapeutisch-psychosomatischen Versorgung der Bevölkerung, Verhandlungen des Deutschen Bundestags, Drucksache 7/4200, Bonn Bad Godesberg, Heger, 1975; Asmus Finzen, 'Von der
}

Psychiatrie-Enquete zur postmodernen Psychiatrie', Psychiatr. Praxis, 1987, 14: 35-40.

${ }^{86}$ Paul-Otto Schmidt-Michel, Die

Psychiatrische Familienpflege. Medizin-historische Entwicklung und Evaluation eines Projektes, Ulm, Universitätsschrift, 1989; Peter Stolz, 'Betreuung psychisch kranker Menschen in GastfamilienPilotprojekt im Land Brandenburg', in H Ortmann, $\mathrm{H}$ Walter (eds), Sozialmedizin in der Sozialarbeit. Forschungen für die Praxis, Berlin, Verlag für Wissenschaft und Forschung, 2000, pp. 111-23. ${ }^{87} \mathrm{G}$ Brugger, 'Arbeitsplätze für psychisch Behinderte vermitteln und erhalten-wie soll das gehen?', Psychiatr. Praxis, 1995, 22: 249-51. 


\section{Social Psychiatry in Germany in the Twentieth Century}

change their attitude to the mentally ill, so that the process of integration became a mutual one. Despite such positive examples, many of the Psychiatrie-Enquete's proposals were not implemented. Also, the anchoring of social psychiatry in medical faculties had little success in the late 1970s and 1980s. It is, however, true that some of the protagonists of social psychiatry, such as Klaus Dörner, Asmus Finzen, Heinz H Häfner, and Gregor Bosch were based at universities. Two independent academic departments were established at the universities of Hanover and Berlin; the Central Institute for Mental Health in Mannheim partly pursued a social psychiatric agenda, and a number of additional chairs were funded with the title "social psychiatry". Yet these activities were isolated. The candidates who were appointed to chairs of social psychiatry often came from a biologically oriented background, and academic research in social psychiatry materialized only sporadically. At the end of the twentieth century, the Central Institute for Mental Health had more or less given up social psychiatric research, one of the two departments for social psychiatry had disappeared and academic chairs for social psychiatry had been renamed. However, the reforms did have some effect on university hospitals. Most of them took over catchment area responsibilities, thus giving up-partially and reluctantly - their rights to select patients and refer to other institutions all those patients who were deemed as being of no interest for research and teaching. Furthermore, in the 1990s aspects of social psychiatry were included in the newly developed curricula for the postgraduate training of psychiatrists. However, these aspects mainly concerned epidemiology and social factors in the aetiology of disorders, and hardly dealt with methods of community based care.

Whilst the impact of reforms on university hospitals may have been limited, practical care changed dramatically following the publication in 1975 of the Psychiatrie-Enquete and of a related report of an "expert commission" in 1988. Most notably, asylums were downsized and conditions on wards improved with better physical facilities and more favourable patient-staff ratios. Unlike the United Kingdom, asylums were not closed down-by 2000 only one in Merzig had been closed completely-and the number of beds only started to fall in the 1990s as a result of economic pressures. The reduction of beds in asylums was more than compensated by additional beds in newly established psychiatric wards at general district hospitals. The integration of psychiatric hospital care into general medical hospital care was seen as a central component of the reforms. Subsequently, a debate emerged between psychiatrists in asylums and general hospitals about the further need for asylums. By the end of the century, most asylums were not only downsized, but the nature and quality of their care had also changed so that they bore more resemblance to units in general hospitals and the debate became less important.

The era following the Psychiatrie-Enquete witnessed substantial investment in community-based services, in particular facilities for social contacts, occupational activities and supported housing. These services provided a wide range of care interventions and were often, by comparison with other European countries, well staffed. Yet the funding system led to a fragmentation of services with no agency responsible for the continuity and coordination of care for individual patients. Most community-based services were funded by social welfare, and as such not directly part of the health care system. Typically, different public and private non-profit providers competed for the same funds in the same catchment 


\section{Heinz-Peter Schmiedebach and Stefan Priebe}

area resulting in a range of organizations providing isolated aspects of care for the same patients. Thus the reforms initiated by the Psychiatrie-Enquete led to the implementation of extensive community-based care, but did not resolve the dilemma of a structurally fragmented mental health care system. After re-unification this problem extended to the area of the former GDR, which adopted the political and health care system of the Federal Republic.

\section{Driving Forces in Social Psychiatry}

Who and what were the main catalysts of this social psychiatric orientation? During the whole period university psychiatrists only sporadically played a role in these developments, except for Eugen Bleuler, who in 1905 called for the early discharge of patients with severe mental diseases. ${ }^{88}$ The psychiatrists of the first half of the twentieth century who developed the models and who were engaged in the realization of their ideas worked in asylums as directors or in other leading positions. Many of them had obtained advanced university degrees, such as the Habilitation, which was a prerequisite for appointment as a university professor. Yet their later careers were spent in the asylums where they were confronted with overcrowding and other problems. In contrast to these asylums, which served as the final home in the institutional lives of a large number of permanently institutionalized patients, the psychiatric university hospitals had the character of transit hospitals where the patients stayed only as long as their presence was needed in order to meet the requirements of research and teaching. In 1931 Valentin Faltlhauser stressed that the only exceptions to this rule were the two university hospitals in Düsseldorf and Frankfurt because their clinics also served as public asylums. ${ }^{89}$ But as a rule, wherever communal or provincial asylums existed, university clinics had to transfer their long-term patients to these institutions. Hence, psychiatrists at university clinics were not confronted with the problems resulting from long-term institutionalization and connected with the psychiatric care of chronic patients. It is therefore hardly surprising that it was mainly asylum doctors who attempted to solve these problems and engage themselves in the development of new forms of psychiatric open care, which relieved the asylums of many difficulties.

While performing this task, the asylum's psychiatrists inevitably had to open up to methods of the social sciences and social hygiene. The adoption of these and their application to psychiatric care led to the models discussed above. With this step they enhanced the spectrum of research methods as well as of psychiatric care. Yet if we consider how reluctantly medical faculties at the beginning 1920s reacted to the attempts to establish social hygiene, ${ }^{90}$ it is easy to understand that this newly emerging social psychiatric discipline could not find the support of other faculty members. The socio-medical or socio-hygienic approach was not welcomed at the medical faculties,

\footnotetext{
${ }^{88}$ Eugen Bleuler, 'Frühe Entlassung', Psychiatr-neurol. Wochenschr., 1905: 441-4.

${ }^{89}$ Valentin Faltlhauser, 'Offene psychiatrische Fürsorge von der Anstalt aus in der Großstadt', in Bumke, Kolb,
}

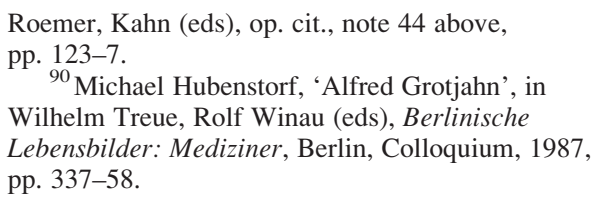




\section{Social Psychiatry in Germany in the Twentieth Century}

although at this time the social sciences enjoyed considerable academic prestige outside the medical faculties.

The situation from the 1960s onwards was slightly different from that of the early decades of the twentieth century. The shift towards social psychiatry was due to a strong socio-political movement. Thus it was public pressure to alleviate the obviously harmful conditions of psychiatric care which led to the widespread activities. Yet because of these public and political contexts, social psychiatric reforms seemed not to be primarily a question of medical therapy, but of political priorities and decision making. The concept of social psychiatry seemed to be rooted in moral and political considerations, not in medical discussions on the improvement of psychiatry. The new social psychiatry suffered from being viewed as a moral and political attitude, and opponents referred to it as social romanticism. Therefore the medical faculties saw no reason to accept this "non-scientific" approach. Of course, there were some strong efforts aimed at the development of sufficient social psychiatric methods of research and therapy, but when the political pressure eased and asylum conditions improved, the public lost interest in the issue and the faculties were able to confine themselves to what they considered their core tasks. However, the activities of the above mentioned few protagonists of social psychiatry, who were based at universities, had an essential impact on the development of social psychiatry. Because of strong political pressure and a special-although short-lived-zeitgeist following the student rebellion in 1968, a small number of medical faculties appointed social psychiatrists to leading academic positions (approximately 10 to 15 per cent of all medical faculties in West Germany). These psychiatrists continued their commitment to social psychiatric affairs and to promoting reforms, often separated from and without any contacts with their strongly medically oriented colleagues at the same or other faculties.

The problem of financial resources did not seem hinder the development of models of psychiatric ambulant care and their implementation. On the contrary, when in the first decades of the twentieth century economic issues were considered, the cost-savings accruing from the establishment of ambulant care functioned as an important argument for this method of treatment. When the new discussion in the 1960s arose it did so in an era of economic prosperity, therefore, the question of the funding needed for the realization of the new models was pushed into the background. In the German Democratic Republic occupational therapy was used to integrate mentally ill patients into industrial work. This was intended to compensate for the general shortage of manpower in the East German economy and to help the rehabilitation of the mentally ill. In addition, the socialist self-image did not allow for questions of medical care to be subject to economic considerations. A lack of funds was not, therefore, an obstacle to the development of psychiatric ambulant care.

In the early decades of the twentieth century at least and in the Federal Republic of Germany another factor that significantly influenced ambulant psychiatric care has to be taken into consideration: resident (niedergelassenen) or office based psychiatrists, who-either as panel doctors or as private doctors-had the privilege of practising medicine. In 1931 Faltlhauser had already underlined the rights of these psychiatrists, which had to be respected by the care institutions. He also stressed that psychiatrists in charge of ambulant care had to be aware that medical treatment in the community was 


\section{Heinz-Peter Schmiedebach and Stefan Priebe}

not part of their responsibilities. If a treatment was considered necessary, the doctor of the care institution was obliged to contact the resident psychiatrist and let him do his work. ${ }^{91}$ Since the resident doctors, who traced their origins back to the early twentieth century, formed a strong lobby and did not hesitate to use their power, it is not surprising that Faltlhauser addressed this problem. In the Federal Republic of Germany the position of resident doctors grew even stronger because they were seen as symbols of a free health care system as opposed to that of the German Democratic Republic with its socialist compulsory character. Legally they were commissioned to secure the ambulant care of the population (Sicherstellungsauftrag), which gave them a central position in medical care planning. The resident psychiatrists were not opposed to particular forms of housing and work, yet they were eager to defend their exclusive entitlements to practise medicine outside hospitals. This was fuelled by a funding system that provided income based on the number of patients in the care of a given doctor working in office practice. Thus, for economic reasons, office-based psychiatrists were opposed to other community-based services providing medical treatment in addition to social support and, sometimes, psychological therapy. Because of this, the ambulant care system was forced to focus on advice, consultation, registration and surveillance, and on the development of new forms of housing and work. The role of the local public health services, the Gesundheitsämter, changed over time. Until the early 1930s they were communal institutions, later in NS Germany they became institutions of the state. They gave advice, were active in prevention (immunization), registered and kept sick people under surveillance, including mentally ill individuals. They collaborated with the other institutions of social or psychiatric care, but never took the initiative for social psychiatric reforms. In National Socialist times the Gesundheitsämter had to undertake the hereditary evaluation of people, particularly of couples who wanted to marry. In the post-war period the Gesundheitsämter were-in their psychiatric function-excluded from medical treatment and provided emergency assessments and general social interventions linked to social care rather than the health care system.

\section{Conclusion}

In the early twentieth-century, psychiatry in Germany took new steps to expand its influence. In the first half of the nineteenth century psychiatrists had started the first initiative: they had framed the asylum as a social entity that was governed by psychiatrists who considered themselves benevolent rulers of their own little realm. From the 1860s they took a second step: psychiatry became an academic discipline at the medical faculties of German universities. The new roles of psychiatrists as academic teachers and directors of university hospitals were legitimized by the application of new scientific methods to the investigation of insanity. The third step, the establishment of models of ambulant psychiatric care in communities, enabled psychiatrists to extend their influence over people outside the asylums and the university clinics. The psychiatrists needed the outpatients in order to extricate themselves from the closed

${ }^{91}$ Faltlhauser, op. cit., note 89 above, p. 126. 


\section{Social Psychiatry in Germany in the Twentieth Century}

environment of asylums. This step was connected to the adoption of new methods of epidemiological research, and to the development of the new roles of psychiatrists as advisers, controllers and supervisors in all matters of mental health and hygiene. Moreover, psychiatrists offered their services as competent experts for the prevention of insanity by applying biological methods in order to establish eugenics. This third step was in part a pragmatic response to problems which arose out of asylum care, such as limited space and large numbers of patients. The psychiatrists sought to become important experts in managing the effective distribution of human resources in society. This development can be characterized as part of a process of modernization which aimed to regulate all social intercourse by scientifically derived specifications developed by special groups of academic experts-among others, psychiatrists.

At the beginning of the twentieth century, psychiatrists used the term "social" in various ways: it pointed to both the social causes of mental diseases as well as to the effects of insanity and mental anomalies on society; alongside these two meanings, the term "social" bridged the gap to social hygiene, another newly emerging medical discipline. Hence "social" became a symbol for the competence of psychiatry to locate solutions to social problems and, in doing so, it, fourthly, established priorities and put the real or alleged interests of social groups, communities, and the state in the foreground.

From the 1950s the situation changed. Psychiatrists from both German states attempted to refer to the social psychiatric models of the first three decades of the twentieth century in order to integrate as many patients as possible into their old social environment. This primarily pragmatic attitude was amalgamated with another connotation of the "social" that had more to do with emancipation and equal rights, etc. In the 1960s and 1970s suppressed people throughout the world, the people of the French and Portuguese colonies as well as minorities in the industrialized countries, among them the mentally ill, were seen as victims who needed to be liberated from their oppressors. Social action meant acting in a humane way that also respected the equal rights of all people. This connotation of the term "social" influenced psychiatrists in both German states. The programme of Rodewisch encompassed several such issues. The open care system from the first half of the twentieth century aimed at integrating psychiatry in the community; later initiatives focused on integrating the patients.

In contrast to the situation in the Federal Republic, a socio-political movement calling for a new society based on these social principles did not emerge in the GDR. Therefore the psychiatrists of the GDR who demanded reforms remained a small group, active only within the limits determined by the political administrative apparatus. By contrast, reform oriented psychiatrists in the FRG who used the term social were part of this particular socio-political movement and could benefit from its power. They aimed at the social inclusion of the weakest members of society. Alongside these emancipatory and humane connotations, the term "social" in the context of psychiatry in the FRG was amalgamated with two other important points. First, it indicated socially determined causes of mental disturbances. This approach fitted very well into the political demands for a new humane society. It was hoped that the newly created social environment would minimize the causes of mental illness. In addressing this issue, psychiatrists used the political movement in order to empower their social psychiatric activities. Social psychiatric reforms were inevitably connected to 
political and social reforms. Second, the term "social" was used to define new tasks of social psychiatric research as well as to adopt certain methods derived from the social sciences. But this could not foster the academic institutionalization of the newly emerged psychiatric subdiscipline. Moreover, as the socio-political situation changed and the reform movement of the 1960s declined in power, the social psychiatric reform impetus became weaker. It was replaced by a more pragmatic attitude. The reform spirit was not strong enough to overcome old structures. 